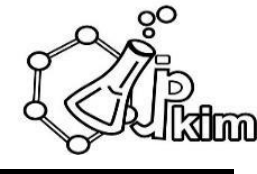

\title{
KOMPARASI PRAKTIKUM RIIL DAN PRAKTIKUM VIRTUALTERHADAP HASIL BELAJAR KIMIA SISWA SMA PADA PEMBELAJARAN LARUTAN PENYANGGA
}

Agustina Dewi, Tika, Suardana,

Universitas Pendidikan Ganesha Singaraja, Bali, Indonesia

\section{A R T I C L E I N F O \\ Article history: \\ Received 04 October 2019 \\ Received in revised form \\ 7 October 2019 \\ Accepted 9 October 2019 \\ Available online 12 October 2019 \\ Kata Kunci:}

Hasil belajar kimia, praktikum riil, praktikum virtual

\begin{abstract}
ABSTRAK
Penelitian ini bertujuan mendeskripsikan dan menjelaskan perbedaan hasil belajar kimia, antara siswa yang mengikuti pembelajaran dengan praktikum riil dan virtual. Penelitian ini merupakan eksperimen semu dengan rancangan non equivalent pretest-posttest control group design. Populasi penelitian adalah siswa kelas XI IPA SMA Laboratorium Undiksha Singaraja tahun ajaran 2017/2018. Sampel penelitian ini adalah siswa kelas XI IPA 1 sebagai kelas eksperimen dan siswa kelas XI IPA 2 sebagai kelas kontrol yang dipilih dengan teknik cluster random sampling. Siswa kelas eksperimen dibelajarkan dengan praktikum virtual dan siswa di kelas kontrol dibelajarkan dengan praktikum riil. Data dianalisis dengan teknik analisis deskriptif dan inferensial. Analisis deskriptif hasil belajar kimia siswa dideskripsikan berupa skor rata-rata pre-test dan post-test siswa. Analisis inferensial hasil belajar kimia siswa menggunakan analisis kovarian (Anakova). Hasil uji Anakova menunjukkan nilai
\end{abstract} signifikansi sebesar 0,041, yang artinya terdapat perbedaan yang signifikan hasil belajar siswa yang dibelajarkan dengan praktikum riil dan virtual. Skor rata-rata hasil belajar siswa di kelas kontrol $(81,55)$ lebih baik dibandingkan dengan kelas eksperimen $(79,22)$.

\section{ABSTRACT}

This research was aimed to describe and explain the differences of high school student's achievement between students who followed learning process with real practicum and virtual practicum. The research was conducted on the topic of buffer. It is a quasi-experiment research with nonequivalent pre-test post-test control group design. The population was the student of class XI IPA SMA Laboratorium Undiksha on academic year 2017/2018. The samples were the students of XI IPA 1 class as experimental class and the students of XI IPA 2 class as control class that selected with cluster random sampling technique.The students in the experimental class followed the learning process with virtual practicum and the student in control class followed the learning process with real practicum. The data of chemistry student's achievement were collected using the student achievement test. The data were analyzed with descriptive and inferential analysis.Descriptive analysis of chemistry student's achievement were described in the form of the mean score of student's pre-test and post-test. Inferential analysis of chemistry student's achievement were analyzed using covarian analysis (Anacova). The Anacova test result showed the significant level on 0,041, which shown there were the significant differences of High school student's achievement between the student who followed learning process with real practicum and virtual practicum. The mean score of student's achievement in control class $(81,55)$ was higher than experimental class $(79,22)$.

Keywords: chemistry student's achievemen, real practicum, virtual practicumt.

\footnotetext{
${ }^{1}$ Corresponding author.
} 


\section{PENDAHULUAN}

Kimia merupakan cabang Ilmu Pengetahuan Alam yang mempelajari tentang struktur, komposisi materi, perubahan materi dan energi yang menyertai perubahan materi. Pada hakekatnya ilmu kimia mencakup dua hal, yaitu kimia sebagai produk dan kimia sebagai proses. Kimia sebagai produk mencakup sekumpulan pengetahuan yang berupa fakta, prinsip, konsep, teori, dan hukum. Kimia sebagai proses mencakup keterampilan dan sikap yang harus dimiliki untuk memperoleh dan mengembangkan pengetahuan tentang kimia. Oleh sebab itu, dalam mempelajari kimia harus memperhatikan karakteristik ilmu kimia sebagai produk dan proses (Keenan, 1986).

Proses pembelajaran sesuai Kurikulum Tingkat Satuan Pendidikan (KTSP), diharapkan berpusat pada siswa (Permendiknas No. 23, 2006). Siswa diharapkan dapat memiliki berbagai pengalaman belajar untuk memahami konsep dan proses sains. Pengalaman belajar tersebut dapat tercermin melalui kegiatan seperti melakukan praktikum, mengamati fenomena, dan mendiskusikan fenomena. Kegiatan praktikum akan memberikan pengalaman langsung kepada siswa yang dilakukan melalui kerja ilmiah. Kerja ilmiah melatih siswa untuk menemukan konsepnya sendiri, sebagai dasar untuk berpikir kreatif dan kritis sehingga diharapkan siswa dapat menemukan hubungan antarvariabel. Selain itu, kerja ilmiah juga melatih siswa dalam melaksanakan praktikum untuk mengumpulkan data, menyajikan hasil, menganalisis data, menyimpulkan, dan mengomunikasikan hasil.

Salah satu materi kimia yang dirancang untuk melaksanaka praktikum adalah larutan penyangga. Materi larutan penyangga merupakan materi yang sangat berkaitan dengan kehidupan sehari-hari. Dalam mempelajari materi larutan penyangga, diperlukan untuk menghubungkan tiga level representasi yaitu makroskopik, submikroskopik dan simbolik. Mempelajari materi larutan penyangga seharusnya memberikan kesempatan siswa memiliki pengalaman langsung dalam mengamati fenomena terkait larutan penyangga. Melalui pengalaman langsung siswa diharapkan dapat membangun konsep dan menghubungkannya dengan pengetahuan yang akan diperoleh siswa berikutnya. Guru diharapkan tidak hanya fokus pada aspek perhitungan saja, sehingga siswa dapat memperoleh pemahaman konsep secara utuh.

Namun kenyataannya, temuan Wiratma (2014) yang menyatakan bahwa guru beranggapan pembelajaran dengan praktikum di laboratorium sangat merepotkan dan memerlukan waktu dan tenaga yang banyak, sementara itu untuk keberhasilan menjawab soal ujian akhir bagi anak-anak, lebih efektif dengan cara latihan soal-soal. Hal serupa juga ditemukan di SMA Labratorium Undiksha. Hasil wawancara yang dilaksanakan pada hari senin tanggal 26 maret 2018 dengan Bapak Drs. Wayan Padayasa memperoleh hasil bahwa proses pembelajaran dengan memberikan latihan soal dianggap lebih efektif dibandingkan memberikan kegiatan praktikum kepada siswa. Kegiatan praktikum membuat siswa sibuk dengan kegiatan sementara waktu belajar terbatas. Hal ini tentunya berdampak pada hasil belajar siswa yang rendah.

Berdasarkan temuan tersebut, maka perlu diterapkan proses pembelajaran yang menempatkan siswa secara aktif terlibat dan membangun konsepnya sendiri melalui pengalaman langsung. Proses pembelajaran yang melibatkan siswa secara aktif melakukan dan berpikir dapat diwujudkan dalam kegiatan praktikum. Praktikum merupakan salah satu cara belajar yang efektif dengan menyertakan peran aktif siswa yang berguna meningkatkan daya ingat dalam pembelajaran.

Kegiatan praktikum memerlukan sarana berupa laboratorium. Laboratorium merupakan tempat untuk mengaplikasikan teori keilmuan, pengujian teoritis, dan pembuktian uji coba penelitian dengan menggunakan alat bantu yang menjadi kelengkapan dari fasilitas dengan kuantitas dan kualitas yang memadai (Depdiknas, 2002). Praktikum di laboratorium memberikan kesempatan siswa membuktikan teori-teori yang telah dipelajari. Selain itu, siswa mendapat kesempatan untuk mengembangkan kemampuan psikomotoriknya seperti keterampilan menggunakan alat dan bahan di laboratorium, mengurangi ceramah dalam proses pembelajaran, memberi peluang lebih besar kepada siswa untuk melatih daya nalar, imajinasi dan berpikir rasional dalam mencari kebenaran, melatih siswa menerapkan sikap dan metode ilmiah dalam menghadapi segala persoalan sehingga tidak mudah percaya terhadap sesuatu yang belum pasti kebenarannya (Roestiyah, 2008). Namun, pada kenyataannya tidak semua guru-guru kimia melaksanakan praktikum dalam proses pembelajarannya. Kegiatan praktikum di sekolah jarang terlaksana karena ada beberapa kendala yang dihadapi. Beberapa kendala yang sering dihadapi, antara lain (1) merencanakan dan mengaplikasikan pembelajaran dengan laboratorium dianggap membutuhkan banyak waktu, (2) mengecek kinerja siswa sulit dilakukan pada kelas yang ramai, dan (3) banyaknya alat-alat laboratorium yang rusak sehingga kadang guru hanya melakukan demonstrasi saja (Tuysuz, 2010).

Seiring perkembangan IPTEK, telah banyak muncul media pembelajaran yang dapat digunakan untuk mengatasi kendala- kendala yang dihadapi pada pelaksanaan praktikum di 
laboratorium, salah satunya yaitu menggunakan media pembelajaran laboratorium virtual untuk melaksanakan praktikum secara virtual. Laboratorium virtual adalah serangkaian alat-alat laboratorium yang berbentuk perangkat lunak (software) komputer berbasis multimedia interaktif yang dioperasikan dengan perangkat keras (hardware) komputer dan dapat menyimulasikan kegiatan di laboratorium seakan-akan pengguna berada pada laboratorium sebenarnya (Santoso dalam Yeni, 2015). Media komputer dimanfaatkan dalam pembelajaran karena memberikan keuntungan-keuntungan yang tidak dimiliki oleh media pembelajaran lainnya yaitu kemampuan komputer untuk berinteraksi secara individu dengan siswa (Padmanthara, 2007). Beberapa manfaat yang dapat diperoleh dengan menggunakan laboratorium virtual, diantaranya pembelajaran lebih menarik, lebih interaktif, jumlah waktu mengajar dapat dikurangi serta kualitas belajar dapat ditingkatkan (Reismiyanto, 2008). Akan tetapi penerapan laboratorium virtual tidak dapat memberi kesempatan kepada siswa untuk mengembangkan kemampuan psikomotorik siswa, seperti belajar memasang, menggunakan, dan merakit instrumen praktikum secara langsung, ditambah lagi siswa tidak dapat melibatkan semua inderanya seperti pendengaran, perasaan, penciuman, dan peraba dalam melakukan pengamatan (Lerianti, 2014). Beberapa penelitian menunjukkan bahwa penggunaan laboratorium virtual efisien untuk diterapkan dan memberikan kontribusi yang positif terhadap hasil belajar siswa (Angga, 2014, Herga \& Dinevski, 2012, Tuysuz, 2010).

Berdasarkan kelebihan dan kelemahan yang dimiliki oleh pembelajaran dengan praktikum di laboratorium dan paktikum secara virtual, memunculkan pertanyaan, "apakah terdapat perbedaan hasil belajar kimia antara siswa SMA yang dibelajarkan dengan menggunakan praktikum di laboratorium dan praktikum virtual?". Berdasarkan pemaparan diatas, peneliti ingin mengkaji lebih jauh mengenai komparasi hasil belajar kimia antara siswa yang dibelajarkan dengan menggunakan praktikum di laboratorium dan praktikum virtual di SMA Laboratorium Undiksha.

\section{METODE}

Jenis penelitian pada penelitian ini adalah eksperimen semu (quasi experimental). Eksperimen semu digunakan karena peneliti tidak dapat mengontrol sepenuhnya variabel-variabel yang mempengaruhi penelitian (Sugiyono, 2016). Rancangan penelitian yang digunakan adalah Nonequivalent Pre-test Post-test Control Grup Design. Adapun desain penelitian ini adalah sebagai berikut:

Tabel 1 Non Equivalent Pretest-Postest Control Grup Design

\begin{tabular}{cccc}
\hline Kelas & $\begin{array}{c}\text { Keadaan } \\
\text { awal }\end{array}$ & Perlakuan & $\begin{array}{c}\text { Keadaan } \\
\text { akhir }\end{array}$ \\
\hline Eksperimen & 01 & $\mathrm{X} 1$ & 02 \\
Kontrol & 03 & $\mathrm{X} 2$ & 04 \\
\hline
\end{tabular}

Keterangan :

$\mathrm{X} 1=$ Pembelajaran menggunakan laboratorium virtual.

$\mathrm{X} 2=$ Pembelajaran menggunakan laboratorium riil.

$01=$ Pretest kelompok eksperimen

$\mathrm{O} 2=$ Posttest kelompok eksperimen

$03=$ Pretest kelompok kontrol.

04 = Posttest kelompok kontrol

Populasi pada penelitian ini adalah seluruh siswa kelas XI IPA SMA Laboratorium Undiksha pada semester genap tahun ajaran 2017/2018 yang tersebar di empat kelas yang tidak dibedakan berdasarkan ranking. Sampel pada penelitian ini adalah siswa kelas XI IPA 1 sebagai kelas eksperimen (23 siswa) dan kelas XI IPA 2 sebagai kelas kontrol (24 siswa).

Data yang dikumpulkan adalah hasil belajar kimia siswa (skor pretest dan postest siswa pada kelas kontrol dan eksperimen), yang dikumpulkan dengan cara testing menggunakan tes hasil belajar yang berupa soal pilihan ganda. Tes pilihan ganda berjumlah 25 soal dengan 21 soal dinyatakan valid dan 4 soal dinyatakan tidak valid. Soal memiliki reliabilitas baik dengan nilai reliabilitas sebesar 0,79. Tingkat kesukaran soal meliputi 2 soal tergolong sukar, 10 soal tergolong mudah, dan 13 soal tergolong sedang. Daya beda soal meliputi 16 soal memiliki daya beda baik, 3 soal memilki daya beda cukup, dan 4 soal memiliki daya beda yang jelek. Teknik analisis data yang digunakan pada penelitian ini meliputi analisis statistik deskriptif dan analisis statistik inferensial. Analisis deskriptif digunakan untuk mendeskripsikan data hasil belajar kimia 


\section{HASIL DAN PEMBAHASAN}

Skorpre-test merupakan data yang menunjukkan pengetahuan awal yang dimiliki siswa dan skorpost-test merupakan siswa. Skor hasil belajar siswa dideskripsikan berdasarkan skor rata-rata, standar deviasi, skor maksimal, dan skor minimal pre-test dan post-test siswa. Analisis statistik inferensial yang digunakan untuk menganalisis skor hasil belajar adalah analisis kovarian (Anakova) dengan taraf signifikansi 0.05 dilakukan dengan bantuan SPSS 16 for windows. Uji prasyarat yang dilakukan sebelum analisis data adalah 1) Uji normalitas data dengan Kolmogorov- Smirnov Test dan/atau Shapiro-Wilk, 2) Uji homogenitas variansdengan Levene's Test, 3) Uji linearitas dan keberartian regresi dengan statistic Test of Linierity, dan 4) Uji homogenitas kemiringan garis regresi menggunakan Analysis of Variance data yang menunjukkan hasil belajar yang diperoleh oleh siswa. Skor pre-test danpost- test siswa disajikan pada Tabel 02.

Tabel 2 Deskripsi Umum Nilai Pre-test dan Post-test Siswa Kelas Kontrol dan Kelas Eksperimen

\begin{tabular}{lcccc}
\hline & \multicolumn{2}{c}{ Kelas Eksperimen } & \multicolumn{2}{c}{ Kelas Kontrol } \\
& Pre-test & Post-test & Pre-test & Post-test \\
\hline Nilai rata-rata (mean) & 33,54 & 79,22 & 35,52 & 81,55 \\
Standar Deviasi & 11,71 & 5,60 & 12,64 & 5,67 \\
Nilai Tertinggi & 57,14 & 90,48 & 61,90 & 90,48 \\
Nilai Terendah & 19,05 & 71,43 & 19,05 & 71,43 \\
\hline
\end{tabular}

Berdasarkan Tabel 4.1, skor rata-rata pre-test ini menunjukkan bahwa skor pre-test siswa pada kelas kontrol lebih tinggi daripada kelas eksperimen, namun perbedaan rata- rata skor tersebut tidak jauh berbeda, hal ini menunjukkan bahwa pemahaman awal siswa di kelas kontrol dan di kelas eksperimen tidak jauh berbeda. Sedangkan skor rata-rata post- test siswa yang dibelajarkan dengan praktikum riil lebih tinggi dibandingkan siswa yang dibelajarkan dengan praktikum virtual. Hal ini berarti siswa yang dibelajarkan dengan praktikum riil memiliki hasil belajar yang lebih baik dibandingkan siswa yang dibelajarkan dengan praktikum virtual.

Persebaran nilai posttest siswa digolongkan dalam beberapa kategori, yaitu sangat tinggi, tinggi, sedang, rendah dan sangat rendah. Data post-test yang diperoleh dikategorikan dengan penilaian acuan patokan (PAP). Hasil pengelompokan disajikan pada Tabel 3 . .

Tabel 3 Frekuensi Persebaran Nilai Posttest Siswa

\begin{tabular}{ccccccc}
\hline No & Kriteria & Kategori & \multicolumn{2}{c}{ Kelas Eksperimen } & \multicolumn{2}{c}{ Kelas Kontrol } \\
& & & Frekuensi & Persentase (\%) & Frekuensi & Persentase (\%) \\
\hline 1 & $85-$ & Sangat & 5 & 21,74 & 10 & 41,67 \\
& 100 & Tinggi & & & & 58,33 \\
2 & $70-84$ & Tinggi & 18 & 78,26 & 0 & 0,00 \\
3 & $55-69$ & Sedang & 0 & 0,00 & 0 & 0,00 \\
4 & $40-54$ & Rendah & 0 & 0,00 & 0 & 0,00 \\
5 & $<39$ & Sangat & 0 & 0,00 & & 0 \\
\hline
\end{tabular}

Berdasarkan Tabel 3, diketahui bahwa terdapat perbedaan frekuensi sebaran nilai posttest siswa antara kelas eksperimen dan kelas kontrol. Persentase tersebut menunjukkan bahwa frekuensi sebaran nilai posttest siswa kelas kontrol lebih baik dibandingkan dengan kelas eksperimen.

Mengetahui tingkat signifikansi dengan analisis kovarian (Anakova), terlebih dahulu dilakukan uji prasyarat analisis.Berdasarkan hasil uji prasyarat tersebut diketahui bahwa data pada kelas kontrol dan kelas eksperimen berdistribusi normal, homogen, hubungan antara pemahaman awal (kovariat) dan hasil belajar 
siswa adalah linear dan berarti atau signifikan, serta variabel kovariat dinyatakan tidak berpengaruh secara signifikan terhadap hasil belajar, sehingga jika terdapat perbedaan hasil belajar siswa di kelas kontrol dan di kelas eksperimen disebabkan oleh perbedaan perlakuan yang diberikan dan tidak dipengaruhi oleh pemahaman awal siswa.

Berdasarkan uji prasyarat yang telah dilakukan, data yang diperoleh telah memenuhi persyaratan untuk dilakukan uji Anakova. Hasil uji hipotesis dapat dilihat pada Tabel 04.

\begin{tabular}{|c|c|c|c|c|c|}
\hline Source & $\begin{array}{c}\text { Type III Sum } \\
\text { Squares }\end{array}$ & $D f$ & $\begin{array}{c}\text { Mean } \\
\text { Square }\end{array}$ & $\boldsymbol{F}$ & Sig. \\
\hline Corrected Model & 1327,190 & 2 & 663,595 & 180,804 & .000 \\
\hline Intercept & 21447,966 & 1 & 21447,966 & 5,844E3 & .000 \\
\hline Pretest & 1278,118 & 1 & 1278,118 & 348,238 & .000 \\
\hline Kelas & 16,264 & 1 & 16,264 & 4,431 & .041 \\
\hline Error & 161,491 & 44 & 3,670 & & \\
\hline Total & 306408,291 & 47 & & & \\
\hline Corrected Total & 1488,681 & 46 & & & \\
\hline
\end{tabular}

Berdasarkan data Tabel 4.11, menunjukkan bahwa variabel kelas diproleh nilai F sebesar 4,431 dengan sigifikansi 0,041. Nilai signifikansi tersebut lebih kecil daripada 0,05.

Berdasarkan hasil uji hipotesis yang telah dilakukan, dapat diambil kesimpulan bahwa terdapat perbedaan hasil belajar kimia antara siswa yang dibelajarkan dengan praktikum riil dan praktikum virtual. Pada awal pembelajaran, siswa diberikan pre-test yang bertujuan untuk mengetahui pengetahuan awal siswa terhadap materi yang akan diajarkan. Skor rata-rata pre-test siswa yang belajar dengan menggunakan praktikum riil dan siswa yang dibelajarkan dengan praktikum virtual secara berturut- turut adalah 35,52 dan 33,54. Skor rata-rata pre-test ini menunjukkan bahwa skor pre-test siswa pada kelas kontrol lebih tinggi daripada kelas eksperimen, namun perbedaan rata-rata skor tersebut tidak jauh berbeda, hal ini menunjukkan bahwa pemahaman awal siswa di kelas kontrol dan diambil keputusan bahwa Ho ditolak dan Ha diterima, sehingga dapat diambil kesimpulan bahwa "terdapat perbedaan yang signifikan hasil belajar antara siswa yang dibelajarkan dengan praktikum riil dan praktikum virtual". di kelas eksperimen tidak jauh berbeda. Pengujian hipotesis yang dilakukan tidak dipengaruhi oleh perbedaan hasil pre-test, yang disebabkan pengendalian variabel kovariat oleh anakova sehingga perbedaan hasil belajar yang terjadi memang karena perbedaan perlakukan yang diberikan.

Pada akhir proses pembelajaran, kedua kelompok kelas diberikan post-test yang bertujuan untuk mengetahui hasil belajar siswa setelah diberikan perlakuan. Skor rata-rata post-test siswa yang belajar dengan menggunakan praktikum riil dan siswa yang dibelajarkan dengan praktikum virtual secara berturut-turut adalah 81,55 dan 79,22. Berdasarkan hasil tersebut diketahui bahwa skor ratarata post-test siswa yang dibelajarkan dengan praktikum ril lebih tinggi dibandingkan siswa yang dibelajarkan dengan praktikum virtual. Hal ini berarti siswa yang dibelajarkan dengan praktikum riil memiliki hasil belajar yang lebih baik dibandingkan siswa yang dibelajarkan dengan praktikum virtual. Hasil penelitian ini sejalan dengan hasil penelitian yang dilakukan oleh Saraswaty dkk, (2014), Hamida dkk, (2013), bahwa pelaksanaan praktikum riil memberikan hasil yang lebih baik terhadap peningkatan hasil belajar kognitif siswa.

Perbedaan hasil belajar siswa yang dibelajarkan dengan praktikum riil dan praktikum virtual terjadi karena perbedaan interaksi dan aktivitas siswa selama proses pembelajaran. Terdapat beberapa faktor yang menyebabkan perbedaan hasil belajar siswa yang dibelajarkan dengan praktikum riil dan virtual. Pertama, perbedaan interaksi siswa dengan lingkungannya. Pada praktikum riil, interaksi siswa dengan lingkungan belajarnya terjadi melalui pengalaman langsung. Siswa membangun pemahaman tentang fakta melalui pengalaman langsung melakukan praktikum di laboratorium. Pengalaman langsung dalam praktikum riil didukung oleh pendekatan kontruktivisme (Shiland dalam Ma \& Nickerson, 2006). Pendekatan kontruktivisme menyatakan bahwa pembelajar belajar dengan membentuk suatu konstruk yang kotinyu, membuat kesimpulan, dan membuktikan dengan interaksi secara langsung dengan lingkungannya (Jonassen dalam Bakar, 1991). Pendekatan ini juga menekankan aspek praktik dalam pembelajaran yang menunjukkan bahwa pembelajar seharusnya dapat memperoleh pengalaman langsung menggunakan alat-alat laboratorium (Hardy dalam Bakar,2003). Hal ini tentunya tidak akan didapatkan ketika siswa melakukan praktikum secara virtual. Siswa tidak memperoleh kesempatan berinteraksi dengan alat, bahan dan fenomena secara 
konkrit. Hal ini memungkinkan siswa kesulitan untuk mendeskripsikan peristiwa nyata terkait materi dalam kehidupan sehari- hari dalam laboratorium virtual (Steger, dkk., 2017).

Kedua, karakteristik siswa dan perbedaan gaya belajar siswa. Pemahaman siswa bergantung pada antusiasme siswa dalam menggunakan kemudahan dari praktikum virtual. Rendahnya kemauan siswa untuk melakukan praktikum secara berulang-ulang agar lebih memahami konsep berdampak pada hasil belajar siswa yang rendah. Dengan demikian, cara yang efektif dalam mempelajari sesuatu adalah dengan memberikan kesempatan kepada siswa untuk berinteraksi dengan objek secara langsung, dan berperan aktif selama proses pembelajaran berlangsung. Kegiatan praktikum riil akan mengakomodasi semua gaya belajar siswa dibandingkan hanya berada di depan layar dan mengklik tombol komputer. Hal ini di dukung oleh temuan (Burkett \& Smith, 2016) yang menyatakan bahwa kegiatan praktikum riil dapat mendukung semua gaya belajar siswa, baik pembelajar visual, pembelajar aural, pembelajar verbal, maupun pelajar kinestetik melalui kegiatan-kegiatan persiapan hingga pelaporan kegiatan praktikum. Pengamatan terhadap fenomena selama praktikum seperti, perubahan warna kertas lakmus mendukung siswa yang memiliki gaya belajar visual. Diskusi dan kerjasama mendukung siswa dengan gaya belajar auditori. Penuntun praktikum dan laporan praktikum yang dihasilkan siswa memudahkan bagi siswa dengan gaya belajar verbal, dan kegiatan memanipulasi atau mereaksikan bahan-bahan kimia serta penggunaan peralatan laboratorium bermanfaat bagi siswa dengan gaya belajar kinestetik (Burkett \& Smith, 2016). Praktikum secara virtual hanya mengakomodasi siswa dengan gaya belajar visual dan auditori saja, sehingga siswa dengan gaya belajar kinestetik kurang termotivasi untuk mengikuti pembelajaran.

Ketiga, perbedaan keterlibatan siswa dalam diskusi kelompok. Keterampilan siswa bekerjasama dalam sebuah kelompok ditekankan lebih banyak ketika siswa melakukan praktikum riil daripada praktikum virtual (Ma \& Nickerson, 2006). Keterlibatan siswa dalam praktikum virtual juga kurang, sehingga guru harus lebih berhati-hati dalam menjelaskan relevansi dari eksperimen simulasi kepada siswa (Steger, dkk., 2017). Praktikum riil membangun kemampuan bekerjasama siswa dalam kelompok (Singer dkk dalam Burrket \& Smith, 2016). Siswa harus bekerjasama apabila ingin berhasil melakukan setiap tahapan praktikum. Kerjasama yang dibangun meliputi kegiatan merangkai alat, mengamati, mengumpulkan data, analisis data, pemecahan masalah, hingga pelaporan hasil praktikum riil (Burkett \& Smith, 2016). Siswa akan belajar dari siswa yang lain, karena ketika mereka mendiskusikan materi (contents), akan muncul konflik kognitif, penalaran yang tidak tepat atau miskonsepsi akan terlihat, dan pemahaman yang berkualitas akan terbentuk (Slavin, 2011). Praktikum riil memungkinkan timbulnya interaksi positif antar siswa. Siswa dapat bekerja secara aktif di dalam kelompok, terlebih lagi dalam kelompok siswa memiliki peran yang sama untuk berusaha sebaik mungkin memahami pokok materi dan selanjutnya menjelaskan pada anggota yang lain (Hamida dkk, 2013). Karena adanya interaksi antar siswa dalam diskusi, menyebabkan seluruh anggota siswa dalam kelompok dapat memahami materi dan konsep yang telah disediakan pada latihan soal sebagai bahan diskusi kelompok. Melalui lingkungan belajar yang memungkinkan partisipasi aktif siswa dalam proses pembelajaran menjadikan siswa memiliki kendali atas pembelajaran mereka dan yang berpengaruh pada peningkatan hasil belajar siswa (Olubu, 2015).

Penelitian ini tidak sejalan dengan penelitian dari Putri (2017), Lerianti (2014) Argandi (2013) yang menyatakan bahwa hasil belajar siswa dengan praktikum virtual lebih baik dibandingkan dengan hasil belajar siswa dengan praktikum riil. Hasil penelitian dari Putri (2017) menyatakan bahwa penggunaan laboratorium virtual untuk melaksanakan praktikum secara virtual memberikan rasa nyaman kepada siswa dan lebih menghemat waktu. Siswa tidak merasa takut mengalami kegagalan dalam melaksanakan kegiatan praktikum dan siswa memiliki lebih banyak waktu untuk diskusi dan menyelesaikan masalah dalam LKS. Aktivitas pelaksanaan kegiatan praktikum pada pembelajaran kimia yang tidak pernah dilakukan di sekolah menyebabkan siswa tidak percaya diri dalam menggunakan alat dan bahan praktikum. Hal serupa juga disampaikan oleh Leriani (2014) bahwa

\section{SIMPULAN DAN SARAN}

Berdasarkan hasil penelitian dan pembahasan dapat dibuat simpulan bahwa terdapat perbedaan hasil belajar antara siswa yang dibelajarkan dengan praktikum riil dan praktium virtual. Hasil belajar siswa siswa merasa gugup dan takut melakukan kesalahan dalam memegang alat dan mencampurkan bahan kimia. Selain itu, ketersediaan alat dan bahan yang terbatas menyebabkan siswa kurang bisa bereksplorasi.

Data aktivitas belajar siswa yang dibelajarkan dengan praktikum virtual termasuk ke dalam kategori cukup untuk aspek 1) antusiasme dalam mengikuti pembelajaran, 2) keaktifan siswa menjawab pertanyaan, 3) keaktifan siswa mengajuan pertanyaan, dan 4) kerjasama dalam kelompok, 
serta berada pada aspek aktif pada aspek mempresentasikan hasil diskusi kelompok. Interaksi siswa dengan siswa lainnya cenderung kurang dibandingkan dengan pembelajaran dengan praktikum riil. Respon siswa terhadap penerapan praktikum virtual berada pada kategori positif pada aspek motivasi dan penguasaan konsep, dan kategori sangat positif pada aspek keaktifan.

Berdasarkan pemaparan dari praktikum riil dan virtual tersebut, dapat diketahui bahwa praktikum riil lebih efektif dalam meningkatkan hasil belajar siswa dibandingkan dengan praktikum secara virtual, karena pada praktikum riil memberikan kesempatan siswa untuk membangun konsepnya sendiri melalui pengalaman langsung dan interaksi dengan objek nyata. Oleh karena itu, hasil belajar siswa yang dibelajarkan dengan praktikum riil lebih baik dibandingkan hasil belajar siswa yang dibelajarkan dengan praktikum secara virtual. Penerapan praktikum virtual tidak dapat menjadi pengganti bagi praktikum riil, tetapi sangat berguna ketika tidak memungkinkan melaksanakan praktikum karena beberapa faktor, misalnya, tidak adanya fasilitas laboratorium, atau praktikum yang melibatkan bahan-bahan berbahaya. Praktikum virtual juga berguna sebagai supplement bagi prakikum riil untuk menguatka pemahaman siswa terhadap materi kimia. Dengan menggunakan praktikum riil lebih baik dibandingkan dengan siswa yang dibelajarkan dengan praktikum virtual. Hal ini karena dalam praktikum riil siswa diberi kesempatan untuk berperan secara aktif dalam proses pembelajaran, baik dalam praktikum maupun kegiatan diskusi dengan melibatkan dan mengoptimalkan seluruh inderanya.

Berdasarkan hasil penelitian di atas, dapat diajukan beberapa saran diantaranya guru kimia diharapkan dapat mengkondisikan proses pembelajaran kimia yang disertai dengan kegiatan praktikum di laboratorium, dan sekolah diharapkan dapat mengupayakan ketersediaan fasilitas yang mendukung ketelaksanaan kegiatan prakikum dalam pembelajaran kimia.

\section{DAFTAR RUJUKAN}

Adnyana, G. P. 2011. "Meningkatkan Aktivitas, Kompetensi Kerja Ilmiah, dan Pemahaman Konsep melalui Pembelajaran Problem Solving". Jurnal Pendidikan Kimia Indonesia. Volume 1, Nomor 1, (hlm 67-75).

Angga D. S, Ni Wayan. 2014. Pengaruh Multimedia Pembelajaran Crocodille Chemistry Menggunakan Camtasia Studio 7 terhadap Hasil Belajar Siswa pada Materi Sifat Koligatif Larutan untuk Kelas XII SMA N 11 Kota Jambi. Skripsi. Jambi: Universitas Jambi.

Argandi, R, dkk. 2013. Pembelajaran Kimia dengan Metode Inquiry Terbimbing dilengkapi Kegiatan Laboratorium Real Dan Virtual Pada Pokok Bahasan Pemisahan Campuran. Jurnal Pendidikan Kimia. Volume 2, Nomor 2, (hlm 44-49).

Arikunto, S. 2002. Dasar-Dasar Evaluasi Pendidikan. Jakarta: BinaAksara.

Arikunto, S. 2013. Prosedur Penelitian: Suatu Pendekatan Praktik. Jakarta: Rineka Cipta.

Arsyad, A. 2009. Media Pembelajaran. Jakarta: PT Raja Grafindo Persada.

Bakar, N, dkk. 2013. An Effective Virtual Laboratory Approach for Chemistry.Australian Journal of Basic and Applied Sciences. Volume 7, Nomor 3, (hlm 78-84).

Burrket, V.C \& Smith, C. 2016. Simulated Hand on Position Paper. Electronic Journal of Science Education. Volume 20, Nomor 9, (hlm 14-23)

Depdiknas. 2003. Kurikulum 2004 SMA: Pedoman Khusus Pengembangan Silabusdan Penilaian Mata Pelajaran Kimia. Jakarta Depdiknas.

Edgar, Dale. 1969. Audiovisual Methods in Teaching. NY: Dryden Press.

Georgiou, J,dkk. 2007. A Virtual Reality Laboratory for Distance Education in Chemistry. International Journal of Social and Human Sciences. Volume 1, Nomor 11 (hlm 306-313)

Hamida, N., dkk. 2013. "Studi Komparasi Penggunaan Laboratorium Virtual dan Laboratorium Riil dalam Pembelajaran Student Teams Achievement Division (STAD) terhadap Prestasi Belajar ditinjau dari Kreativitas Siswa pada Materi Pokok Sistem Koloid Kelas XI Semester Genap SMA 
Negeri Banyudo Nomor Tahun Pelajaran 2011/2012".Jurnal Pendidikan Kimia. Volume 2, Nomor 2 (hlm.7-15).

Herga, N.R, and Dinevski, D. 2012. Virtual Laboratory in Chemistry-Experimental Study Of Understanding, Reproduction, and Application Of Acquired Knowledge Of Subject's Chemical Content. Research Paper.Volume 45, Nomor 3, (hlm 108-116).

Indrayanti, N. K. D. 2013. Analisis Daya Dukungdan Pemanfaatan Laboratorium Kimia SMA di Kabupaten Tabanan.Skripsi(tidak dipublikasikan).Singaraja: PPs Undiksha.

Istiana, G.A. 2015. Penerapan Model Pembelajaran Discovery lear- ning untuk Meningkatkan Aktivitas dan Preatasi Belajar Peserta didik Pokok Bahasan Larutan Penyangga pada Peserta didik Kelas XI IPA Semester II SMA Negeri 1 Ngemplak Tahun Pelajaran 2013/2014. Jurnal Pendidikan Kimia. Volume 4, Nomor 2, (hlm 65-73)

Jahro, I. S., dan Susilawati. 2009. Analisis Penerapan Metode Praktikum Pada Pembelajaran Ilmu Kimia Di Sekolah Menengah Atas. Jurnal Pendidikan Kimia. Tersedia pada http:// digilib. unimed.ac.id/ 278 /1/ Iis \% 20 Siti \% 20Jahro.pdf (diakses pada 18 Agustus 2018)

Karyadi, B. 1996.Kimia 2 Petunjuk Guru Sekolah Menengah Umum Kelas 2. Jakarta:Balai Pustaka.

Keenan, C.W. 1986. Ilmu Kimia untuk Universitas Edisi Keenam Jilid 1. Terj. A. Hadyana Pudjaatmaka. Jakarta: Erlangga.

Kirna, I M. (2009). Pengembangan Pemahaman Konseptual Kimia pada Siswa Pemula dengan Model Sinkronisasi Makroskopis dan Submikroskopis Berbantuan Multimedia Interaktif. Laporan Penelitian Fundamental (tidak diterbitkan). Singaraja: Universitas Pendidikan Ganesha.

Lazarowitz, R \& P. Tamir. 1994. Research on Using Laboratory Instruction in Science. Handbook of Research on Science Teaching and Learning. New York: Macmillan Publishing Company.

Lerianti, Eno. 2014. Perbandingan Hasil Belajar dengan Menggunakan Laboratorium Nyata dan Laboratorium Virtual dalam Materi Asam Basa Kelas X IPA SMA Nusantara Kota Jambi. Skripsi. Jambi: Universitas Jambi.

Ma, J \& Nickerson, J.V. 2006. Hands on, Simulated, and Remote Laboratories: A Comparative Literature Review. ACM Computing Surveys. Volume. 38, Nomor. 3, (hlm 13-14)

Mentari. 2014. Analisis Miskonsepsi Siswa Sma Pada Pembelajaran Kimia Untuk Materi Larutan Penyangga. Jurnal Kimia Visvitalis. Volume 2, Nomor 1, (hlm 76-78)

Nana Sudjana. 2000. Dasar-dasar Belajar Mengajar. Bandung: PT Sinar Baru Algensindo.

Olubu, O.M. 2015. Effect of Laboratory Learning Enviroment on Student' Learnig Outcomes in Secondary School Chemistry.International Journal of Art and Sciences.Volume 8, Nomor 2, (hlm 524).

Permendiknas Nomor.23 Tahun 2006 Tentang Standar Kompetensi lulusan Untuk Satuan Pendidikan Dasar dan Menengah. Bandung.

Putri, E.P.K. 2017. Perbedaan Model Pembelajaran Modified Free Inquiry (Mfi) Berbasis Laboratorium Riil Dengan Virtual Pada Pokok Bahasan Laju Reaksi Terhadap Hasil Belajar Kimia siswa SMAN 1 Pasangkayu. Elektronik Jurnal Mitra Sains. Volume 5, Nomor 1, (hlm 26-35).

Ratmini, Wayan Sri. 2017. The Implementation of Chemistry Practicum at SMA Laboratorium Undiksha Singaraja in the School Year 2016/2017. Jurnal Pendidikan Indonesia.Volume 6, Nomor 2, (hlm 242).

Ratumanan, T. G and Laurens, T. 2003. Evaluasi hasil belajar. Semarang: Unesa University Press. 
Redhana, I.W, dkk. 2017.Identification Of Chemistry Learning Problems Viewed From Conceptual Change Model. Jurnal Pendidikan IPA Indonesia.Volume 6, Nomor 2, (hlm 357).

Roestiyah. 2008. StrategiBelajarMengajar. Jakarta: RinekaCipta.

Rustaman, N. Y. 2003. Common Textbook, Strategi Belajar Mengajar Biologi. Yogyakarta: Jurusan Pendidikan Biologi FMIPA UPI JICA.

Saraswaty, S., dkk. 2014. “Pembelajaran Kooperatif Number Head Together (NHT) Berbantuan Media Laboratorium Riil dan Virtual dilengkapi Lembar Kerja Siswa (LKS) pada Materi Termokimia Kelas XI SMAN 1 Karanganyar Tahun Ajaran 2013/2014".Jurnal Pendidikan Kimia, Volume 3, Nomor 1 (hlm.86-94).

Slavin, R.E. 2011. Psikologi Pendidikan Teori dan Praktik. Jakarta: Indeks.

Sudjana. 1996. Metoda Statistika. Bandung: PenerbitTarsito.

SugiyoNomor. 2016. Metode Penelitian Kuantitatif, Kualitatif dan R\&D. Bandung: PT Alfabet.

Sutrisno. 2012. Kreatif Mengembangkan Aktivitas Pembelajaran Berbasis TIK. Jakarta: Referensi.

Thoha, M. C. 2003. Teknik Evaluasi Pendidikan. Raja Grafindo Persada : Jakarta

Tuysuz, C. 2010. The Effect Of The Virtual Laboratory on Student's Achievement and attitude in Chemistry. International Online Jounal of Education Science.Volume 2, Nomor 1, (hlm 37-53).

Vitria, L.N., Utami, B. \& Mulyani, S. (2014). Penerapan Metode Pembelajaran Kooperatif Team Assisted Individualization (TAI) Dilengkapi Handout untuk Meningkatkan Kualitas Proses dan Prestasi Belajar Siswa Pada Materi Larutan Penyangga Kelas XI IPA4 SMAN 2 Karanganyar. Jurnal Pendidikan Kimia, Volume 3, Nomor 4, (hlm 59-65).

Widodo, S.A, dkk. 2017. Analisis faktor tingkat kecemasan, motivasi dan prestasi belajar mahasiswa. Jurnal Taman Cendekia. Volume 1, Nomor 1, (hlm 74-75)

Wiratma, I.G.L, danSubagia, I.W. 2014. PengelolaanLaboratorium Kimia Pada SMA Negeri Di Kota Singaraja: (Acuan Pengembangan Model PanduanPengelolaan Laboratorium Kimia Berbasis Kearifan Lokal Tri Sakti). Jurnal Pendidikan Indonesia.Volume 3, Nomor 2, (hlm 428).

Yanti, S, dkk. 2013. Hubungan antara kecemasan dalam belajar dengan motivasi belajar siswa. Jurnal Ilmiah Konseling. Volume 2, Nomor 1, (hlm 1-6)

Yeni, F. L. 2015. Pengembangan Virtual Laboratory Berbasis Multimedia Interaktif pada Mata Kuliah Microbiology Sub Materi Isolasi Bakteri. Jurnal Pendidikan Matematika dan IPA. Tersedia pada http://jurnal.untan.ac.id/index.ph p/PMP/article/download/17591/1 5010 (diakses pada 22 Desember 2019) 